\title{
Data on the distribution of Hystrichopsylla orientalis fleas (Siphonaptera) in Lithuania
}

\author{
Indrè Lipatova \\ Vytautas Magnus University, \\ K. Donelaičio g. 58, \\ 44248 Kaunas, Lithuania
}

\begin{abstract}
The aim of this study was to present data on the distribution of Hystrichopsylla fleas collected from different animals in Lithuania. The study was done by analyzing collections of fleas from 2011 to 2017. A total of 96 fleas of the genus Hystrichopsylla were collected from nine mammalian species (Apodemus flavicollis, Apodemus agrarius, Micromys minutus, Myodes glareolus, Microtus oeconomus, Microtus arvalis, Sorex araneus, Neomys fodiens, and Glis glis). Morphological analysis showed that all fleas were of the species Hystrichopsylla orientalis Smit, 1956.
\end{abstract}

Keywords: fleas, Hystrichopsylla orientalis, rodents, insectivores

\section{INTRODUCTION}

Fleas (Siphonaptera) are common ectoparasites of mammals and birds in different habitats throughout the world. More than 2500 species within 18 families of fleas are known (Krasnov, 2008). Only five flea families occur on birds and all other species parasitize mammals (Whiting et al., 2008).

The genus Hystrichopsylla Taschenberg, 1880 is composed of more than 30 species/subspecies. Fleas of this genus are the largest fleas in the world, with the body length that can reach up to $10 \mathrm{~mm}$ (Holland, 1957; Rosicky, 1957; BrinckLindroth, Smit, 2007). Fleas of Hystrichopsylla species are more commonly found in nests, but are also found in small amounts on the body of a host (Stanko et al., 2002; Brinck-Lindroth, Smit, 2007; Krasnov, 2008). They are primarily found on insectivores and rodents and occasionally on birds (Brinck-Lindroth, Smit, 2007; Whitaker,

\footnotetext{
*Corresponding author. Email: indre.lipatova@vdu.lt
}

2007). Currently, one member of the genus Hystrichopsylla - Hystrichopsylla talpae Curtis, 1826 (Pakalniškis, Žygutiene, 2004) is on the list of Lithuanian flea fauna. Therefore, the aim of this study was to present data on the distribution of Hystrichopsylla fleas collected from different small animals in Lithuania.

\section{MATERIALS AND METHODS}

Fleas were selected from samples collected from different small animals between 2011 and 2017, and stored in $70 \%$ ethanol at $-20^{\circ} \mathrm{C}$ until further investigation. Identification of fleas before species and sex was done with a stereomicroscope with the aid of keys (Rosicky, 1957; Brinck-Lindroth, Smit, 2007).

Flea samples were fixed on permanent microscopic preparations in Canada balsam (BrinckLindroth, Smit, 2007). The preparations are stored at the Department of Biology, Vytautas Magnus University (Kaunas, Lithuania). Flea samples were also documented using digital camera. 


\section{RESULTS AND DISCUSSION}

In the present study, 96 Hystrichopsylla orientalis Smit, 1956 fleas were collected from nine (Apodemus flavicollis, Apodemus agrarius, Micromys minutus, Myodes glareolus, Microtus oeconomus, Microtus arvalis, Sorex araneus, Neomys fodiens, and Glis glis) mammalian species in ten localities of Lithuania (Table). In previous studies, another flea species of the genus Hystrichopsylla - Hystrichopsylla talpae Curtis, 1826 - was detected on A. flavicollis, A. agrarius, Mus musculus, Microtus agrestis, M. arvalis, and M. glareolus in Lithuania (Likevičienè, 1957; Kadyte, 1964; Jeziorskiene, 1974; Lipatova, Paulauskas, 2010). Moles (Talpa europaea) are pri- mary hosts of Hystrichopsylla fleas. However, they are also found on other small mammals such as voles (Cricetidae), mice (Muridae), and shrews (Soricidae) (Smit, 1957; Brinck-Lindroth, Smit, 2007; Baláž, Zigová, 2020). Hystrichopsylla fleas are found very rarely in the nests of dormice (Libois, 1979; Kirillova et al., 2006). Also, sometimes Hystrichopsylla fleas can parasitize weasels (Mustela), baadgers (Meles), foxes (Vulpes vulpes), rabbits (Oryctolagus cuniculus), birch mice (Sicista betulina), rats (Rattus norvegicus), birds (Anthus trivialis), and even the nests of bumblebees (Bombus) (Skuratowicz, 1967).

Fleas of $H$. orientalis species are morphologically very similar to $H$. talpae species. Their main difference is the number of stout

Table. Distribution of Hystrichopsylla orientalis in small mammals in Lithuania

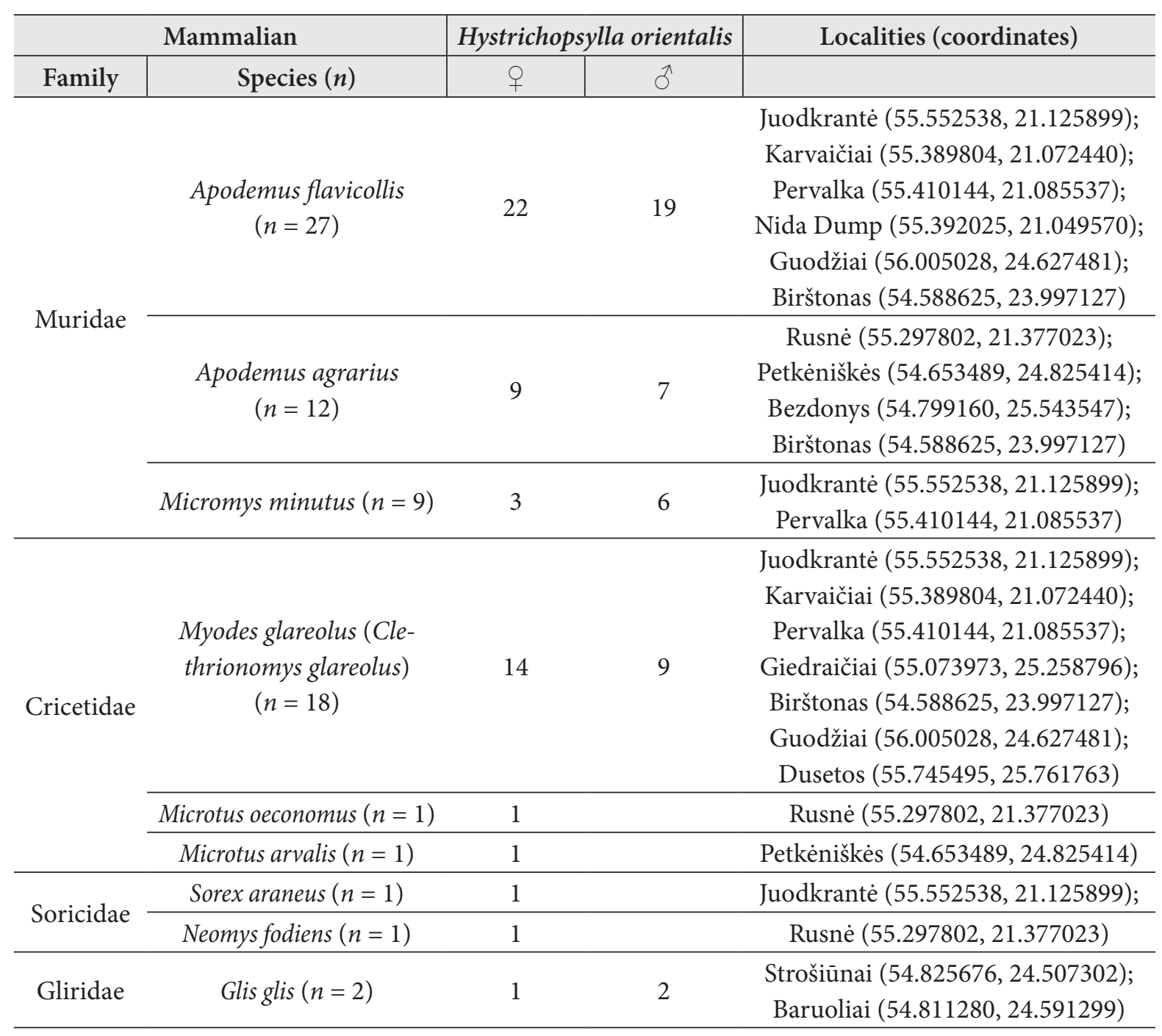

$n-$ number of collected animals 
outer setae on hind tibia. H. orientalis flea species has three setae on the penultimate notch of the posterior margin, while $H$. talpae has only two setae (Figs. 1-2) (Brinck-Lindroth, Smit, 2007). All analyzed Hystrichopsylla fleas had clear three setae on hind tibia (Fig. 3). Females of both species have two spermathecae. However, $H$. orientalis flea species has base of duc-

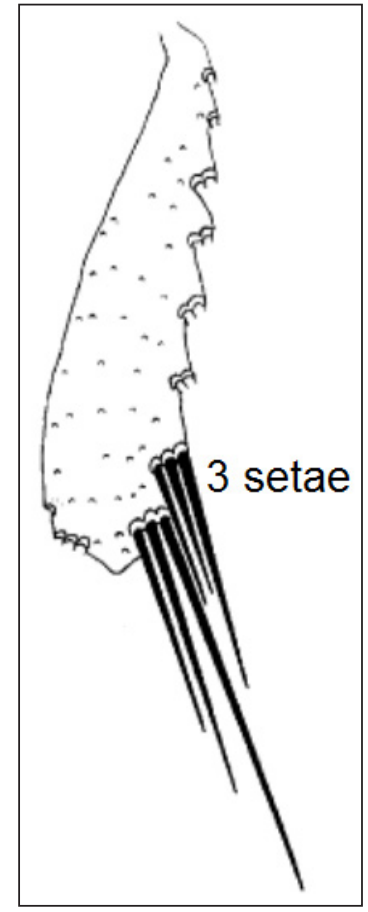

Fig. 1. Hind tibia of Hystrichopsylla orientalis (adapted from BrinckLindroth, Smit, 2007)

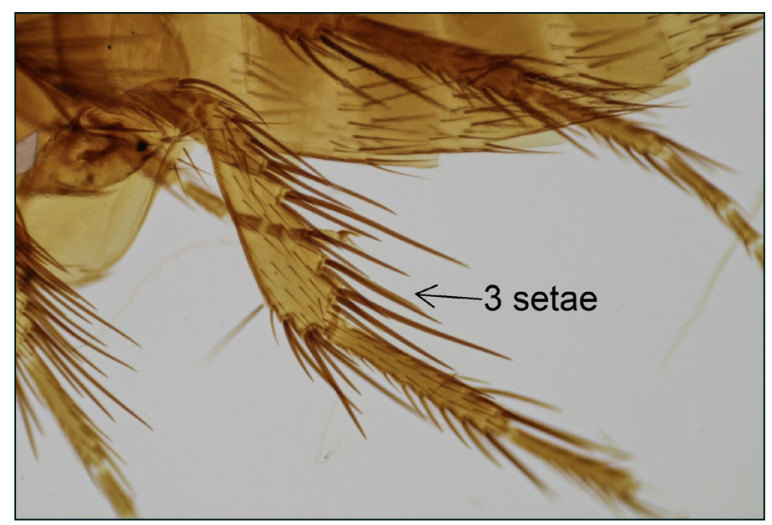

Fig. 3. Representative hind tibia of Hystrichopsylla orientalis collected in Lithuania

Fig. 2. Hind tibia of Hystrichopsylla talpae (adapted from BrinckLindroth, Smit, 2007) tus bursae with dark sclerities, while $H$. talpae has base of ductus bursae without sclerotisation (Fig. 4-5) (Brinck-Lindroth, Smit, 2007). A total of 53 females of Hystrichopsylla species fleas were collected. All of them had sclerotized base of ductus bursae (Fig. 6 A-B). Males

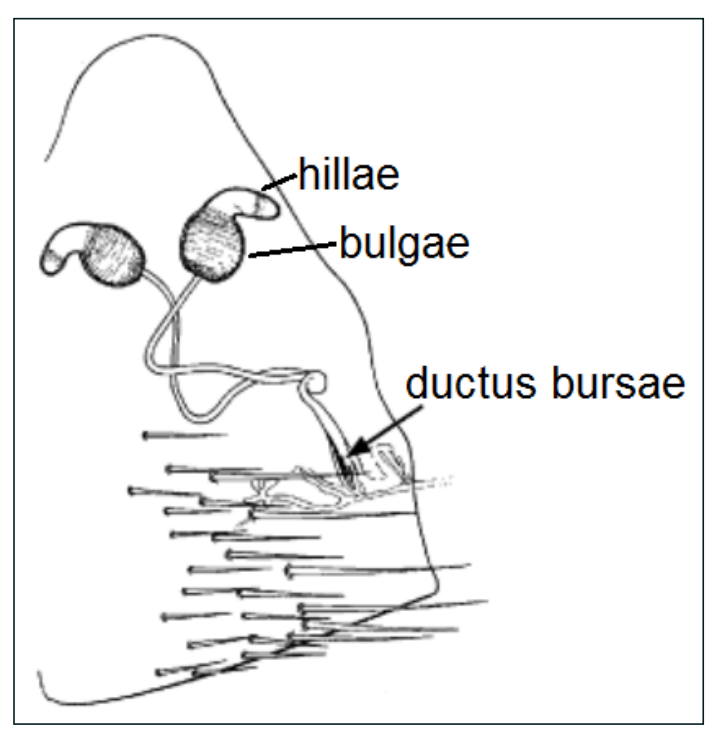

Fig. 4. Spermathecae and ductus bursae of Hystrichopsylla orientalis (adapted from BrinckLindroth, Smit, 2007)

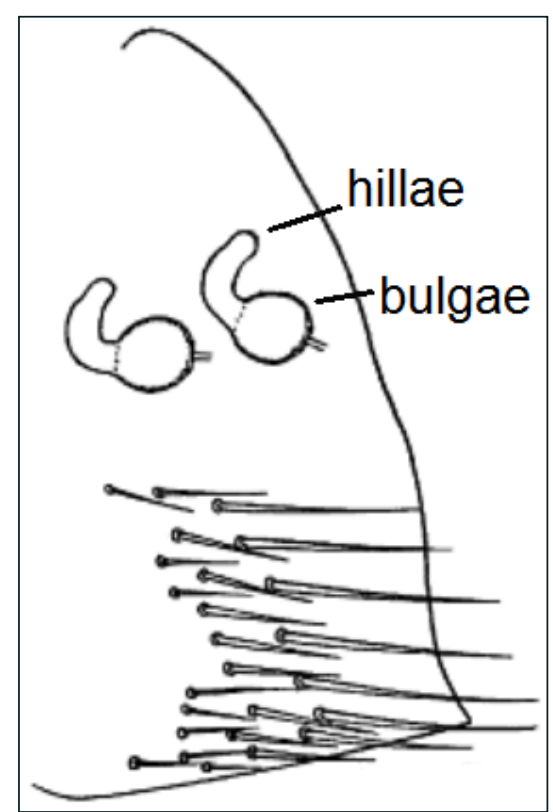

Fig. 5. Spermathecae of Hystrichopsylla talpae (adapted from BrinckLindroth, Smit, 2007) 

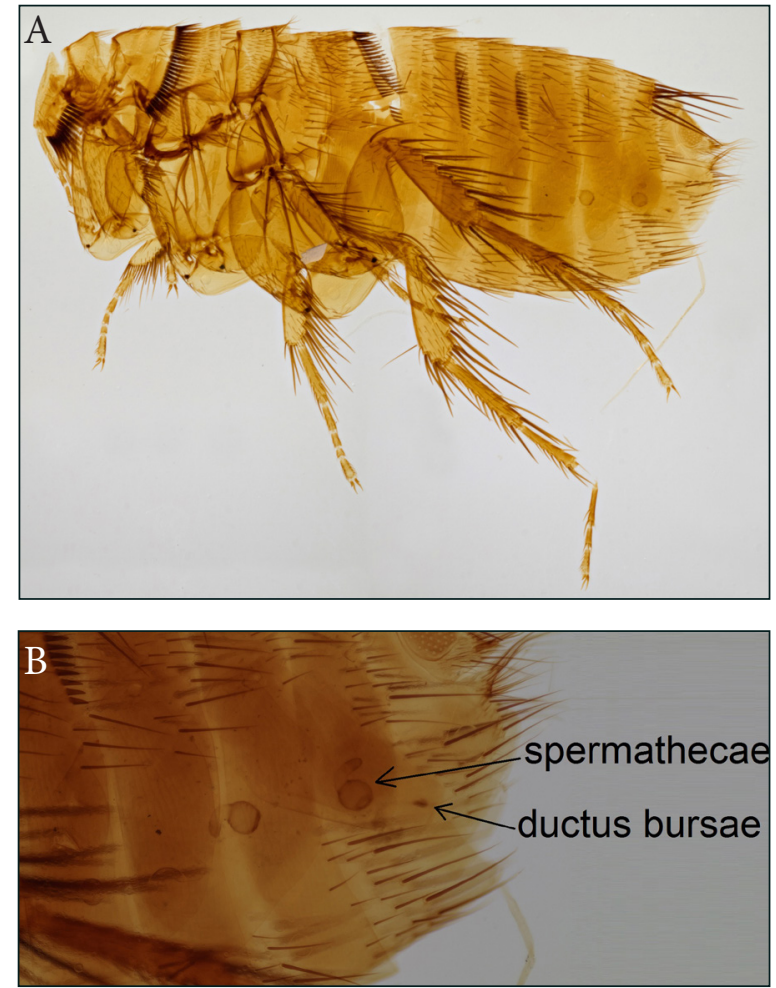

Fig. 6. A. Representative female of Hystrichopsylla orientalis collected in Lithuania; B. Female genitalia

of these two species have small morphological diversity on setae of sternum IX and aedeagus. $H$. orientalis flea species has well separated basal spiniform setae of sternum IX from other crowded together spiniforms, while $H$. talpae has rather widely and uniformly spaced spiniform setae of sternum IX (Fig. 7-8) (BrinckLindroth, Smit, 2007). A total of 43 males of

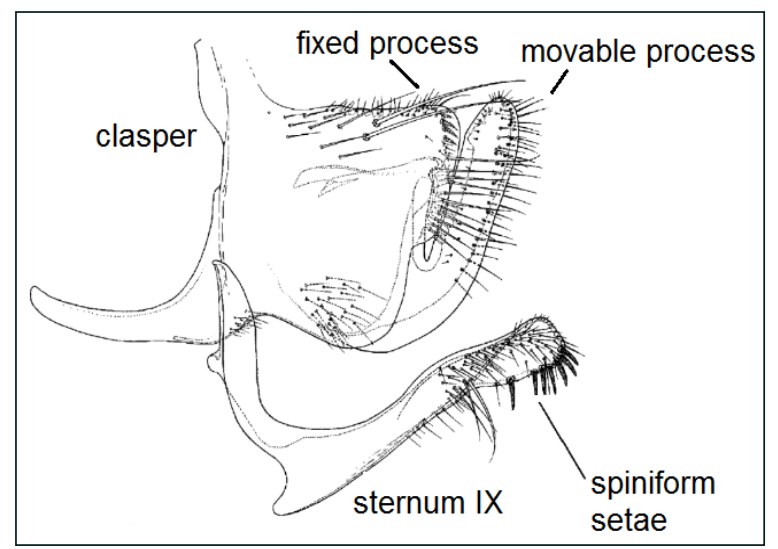

Fig. 7. Sternum IX of Hystrichopsylla orientalis (adapted from Brinck-Lindroth, Smit, 2007)

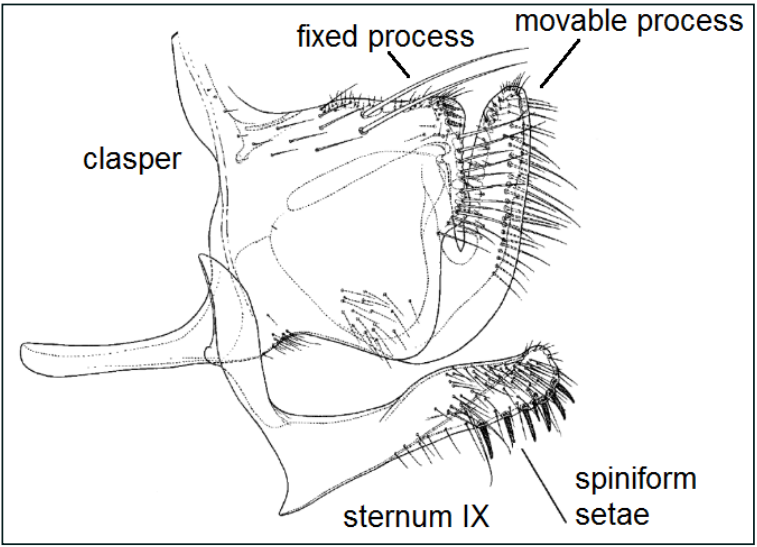

Fig. 8. Sternum IX of Hystrichopsylla talpae (adapted from Brinck-Lindroth, Smit, 2007)

Hystrichopsylla fleas were collected. All of them had basal spiniform setae of sternum IX separated from other spiniforms (Fig. 9 A-B).

Both species of fleas have similar host specificity and the same biology, but the distribution
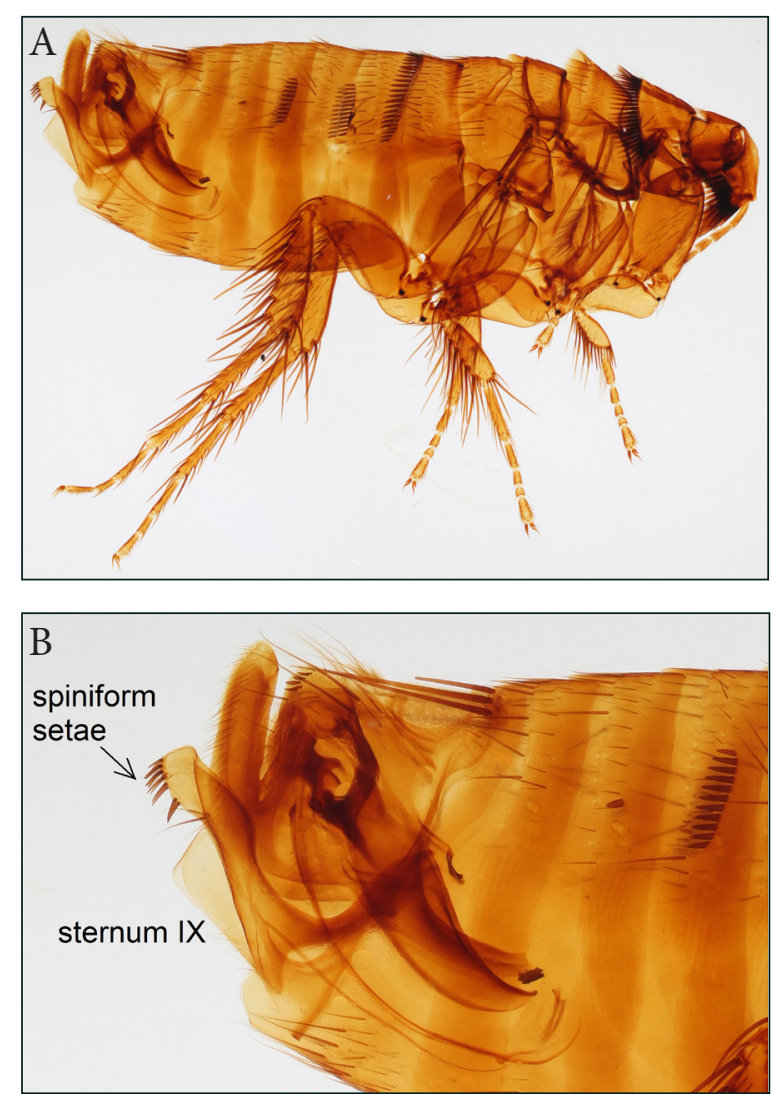

Fig. 9. A. Representative male of Hystrichopsylla orientalis collected in Lithuania; B. Male genitalia 
is slightly different. H. talpae fleas are found in Poland, Latvia, Estonia, Norway, Germany, the Netherlands, Belgium, France, Switzerland, northern Italy, northern Spain, Hungary, the Czech Republic, Slovakia, Austria, Luxembourg, the United Kingdom, Ireland, Denmark, Bulgaria, Greece, Turkey, and extend eastwards to the Krasnoyarsk region in Russia and southwards to the Altai, Tian Shan, and the Caucasus mountains (Holland, 1957; Skuratowicz, 1967; Smit, 1969; Pototski, 1990; Brinck-Lindroth, Smit, 2007; Whitaker, 2007). H. orientalis fleas are distributed in continental and eastern Europe, in southern Poland to Switzerland, in northern Italy, including Russia and Siberia in the east (Smit, 1969; Brinck-Lindroth, Smit, 2007; Baláž, Zigová, 2020). Both species of fleas are found during late summer or autumn. This study is the first report on the presence of $H$. orientalis fleas in Lithuania. Fleas were collected during autumn season (37 in September, 48 in October, and eight in November).

\section{CONCLUSIONS}

The results of this study have shown that $\mathrm{H}$. orientalis fleas are distributed in Lithuania.

\section{ACKNOWLEDGEMENTS}

The author is very grateful to Povilas Sakalauskas for photographing the specimens of Hystrichopsylla orientalis.

Received 25 October 2020

Accepted 25 November 2020

\section{References}

1. Baláž I, Zigová M. Flea communities on small mammals in lowland environment. Ekológia (Bratislava). 2020; 39(3): 260-9.

2. Brinck-Lindroth G, Smit FGAM. The fleas (Siphonaptera) of Fennoscandia and Danmark. Boston: Brill; 2007. p. 31-4.
3. Holland GP. Notes on the genus Hystrichopsylla Rothschild in the New World, with descriptions of one new species and two new subspecies (Siphonaptera: Hystrichopsyllidae). Can Entomol. 1957; 89(07): 309-24.

4. Jeziorskienè E. [Ectoparasites of the bank-vole Clethrionomys glareolus Schreb. under Lithuanian conditions]. Acta Parasit Lit. 1974; 12: 193-7. Russian.

5. Kadyte B. [Rodent fleas in the Lithuanian SSR. In: Materials of the third scientific-coordinated meeting on problems in parasitology of Lithuanian SSR, Latvian SSR and Estonian SSR]. Vilnius; 1964. p. 124-4. Russian.

6. Krasnov B. Functional and evolutionary ecology of fleas: a model for ecological parasitology. Cambridge: Cambridge University Press; 2008. p. 593.

7. Kirillova NY, Kirillov AA, Ivashkina VA. Ectoparasites of the edible dormouse Glis glis L. of Samarskaya Luka Peninsula (Russia). Pol J Ecol. 2006; 54(3): 387-90.

8. Libois RM. Observations on fleas of Common dormouse (Muscardinus avellanurius) in Belgium. Ann Soc R Zool Belg. 1979; 109: 77-85.

9. Likevičienè NM. [Materials on fauna of ectoparasites of some insectivores and rodents of Lithuanian SSR. In: Theses of the scientificcoordinated meeting on problems in parasitology of Lithuanian SSR, Latvian SSR, Estonian SSR and Belorussian SSR]. Vilnius; 1957. p. 26-8. Russian.

10. Lipatova I, Paulauskas A. Investigation of fleas (Insecta: Siphonaptera) in Lithuania. New and rare for Lithuania insect species. 2010; 22: 33-6.

11. Pakalniškis S, Žygutienè M. [An initial list of Lithuanian Siphonaptera]. New and Rare for Lithuania Insect Species. 2004; 16: 74-7. Lithuanian.

12. Rosicky B. Fauna ČSR Blechy - Aphaniptera. Praha: Československa akademie; 1957. p. 446. Czech. 
13. Skuratowicz W. [The keys to determining the Polish insects. Fleas - Siphonaptera (Aphaniptera).] Warszawa: PWN; 1967. p. 46-9. Polish.

14. Smit FGAM. A catalogue of the Siphonaptera of Finland with distribution maps of all Fennoscandian species. Ann Zool Fenn. 1969; 6(1): 47-86.

15. Stanko M, Miklisová D, Bellocq JG, Morand S. Mammal density and patterns of ectoparasite species richness and abundance. Oecologia. 2002; 131: 289-95.

16. Whitaker AP. Fleas (Siphonaptera). Handbooks for the identification of British insects (2nd ed.). London: Royal Entomological Society; 2007. p. 112-5.

17. Whiting MF, Whiting AS, Hastriter MW, Dittmar K. A molecular phylogeny of fleas (Insecta: Siphonaptera): origins and host associations. Cladistics. 2008; 24: 677-707.

\section{Indrè Lipatova}

\section{HYSTRICHOPSYLLA ORIENTALIS RŪŠIES BLUSŲ (SIPHONAPTERA) PAPLITIMAS LIETUVOJE}

\section{Santrauka}

Šio tyrimo tikslas - pateikti duomenis apie Hystrichopsylla genties blusų paplitimą Lietuvoje. Tyrimo metu analizuotos 2011-2017 metų blusų kolekcijos. Iš viso aptikta 96 Hystrichopsylla genties blusos, surinktos nuo 9 rūšių žinduolių (Apodemus flavicollis, Apodemus agrarius, Micromys minutus, Myodes glareolus, Microtus oeconomus, Microtus arvalis, Sorex araneus, Neomys fodiens, Glis glis). Morfologinè analizè rodo, kad visos blusos buvo Hystrichopsylla orientalis Smit, 1956 rūšies.

Raktažodžiai: blusos, Hystrichopsylla orientalis, graužikai, vabzdžiaèdžiai 